ARTICLE

\title{
Netnography of curricular reform for Brazilian high school
}

\author{
Murilo Eduardo Nazário' (D) \\ Wagner dos Santos" (D) \\ Amarílio Ferreira Neto" (D)
}

\section{ABSTRACT}

What are the discursive practices undertaken by the subjects who have discussed the reform of high school in the cyberspace of social media? Who are the subjects practicing these discussions? What are the narratives assumed and disseminated in the content of these speeches? With this investigation, we aim to problematize the ways in which the reform of high school has been approached in social networks with the largest number of users in Brazil. Thus, a netnography was carried out on the interfaces of social networks, Twitter, Facebook, Instagram and Youtube, using as source the written, imagery and audiovisual narratives broadcast by social actors who discussed MP No. 746 in these online places. The results indicate a dispute of narratives and socio-political counter-narratives between the right and the left, demarcated by the subjects themselves, which reverberated on the equation of the impacts that this reform will cause in the daily life of this stage of basic education.

\section{KEYWORDS}

reform; high school; cyberspace. 


\section{NETNOGRAFIA DA REFORMA CURRICULAR DO ENSINO MÉDIO BRASILEIRO}

\section{RESUMO}

Quais são as práticas discursivas empreendidas pelos sujeitos que têm discutido sobre a reforma do ensino médio no ciberespaço das mídias sociais? Quem são os sujeitos praticantes dessas discussões? Quais são as narrativas assumidas e difundidas no conteúdo desses discursos? Com essa investigação, almeja-se problematizar os modos como a reforma do ensino médio tem sido abordada nas redes sociais com maior número de usuários no Brasil. Desse modo, realizou-se uma netnografia nas interfaces das redes sociais, Twitter, Facebook, Instagram e YouTube utilizando como fontes as narrativas escritas, imagéticas e audiovisuais veiculadas por atores sociais que discutiram sobre a MP no 746 nesses lugares online. Os resultados sinalizam para uma disputa de narrativas e contranarrativas sociopolíticas entre direita e esquerda, demarcadas pelos próprios sujeitos, que se reverberam sobre o equacionamento dos impactos que essa reforma provocará no cotidiano dessa etapa da educação básica.

\section{PALAVRAS-CHAVE}

reforma; ensino médio; ciberespaço.

\section{NETNOGRAFÍA DE LA REFORMA CURRICULAR DE LA ESCUELA SECUNDARIA BRASILEÑA}

\section{RESUMEN}

¿Cuáles son las prácticas discursivas emprendidas por los sujetos que han discutido la reforma de la escuela secundaria en el ciberespacio de las redes sociales? ¿Quiénes son los sujetos que practican estas discusiones? $¿$ Cuáles son las narraciones asumidas y difundidas en el contenido de estos discursos? Con esta investigación, nuestro objetivo es problematizar las formas en que se ha abordado la reforma de la escuela secundaria en las redes sociales con el mayor número de usuarios en Brasil. Así, se realizó una netnografía en las interfaces de las redes sociales, Twitter, Facebook, Instagram y Youtube, utilizando como fuente las narraciones escritas, de imágenes y audiovisuales transmitidas por actores sociales que discutieron el MP No. 746 en estos sitios en línea. Los resultados apuntan a una disputa de narrativas y contra-narrativas sociopolíticas entre la derecha y la izquierda, demarcadas por los propios sujetos, que repercutieron en la ecuación de los impactos que esta reforma causará en la vida cotidiana de esta etapa de la educación básica.

\section{PALABRAS CLAVE}

reforma; preparatoria; ciberespacio. 


\section{INTRODUCTION}

On September 22 $2^{\text {nd }}, 2016$, Brazil's Minister of Education sent to the National Congress, through Provisional Measure No. 746, a plan for the reform of Brazilian high school education. The measure would reorganize and arrange curricular components into formative itineraries, namely: languages and their technologies; natural sciences and their technologies; mathematics and their technologies; applied human and social sciences; and technical and professional education. After one and a half years of classes, students would choose one of these itineraries, which they would follow until concluding high school.

However, the final text, which altered the national Law of Guidelines and Bases for Education (LDB) No. 9.394/1996 (Brasil, 2017b) and helped to reduce the National Curriculum Guidelines for Basic Education, left no guidance about the main questions concerning the structure, offer and sharing of the curricular components to be provided in one of the five educational itineraries. Some of these issues remained within the definition established by the implantation of the National Common Curricular Base (Diretrizes Curriculares Nacionais da Educação Básica - BNCC) ${ }^{1}$.

Nearly instantaneously, these changes triggered a series of manifestations, from entities such as the National Association of Graduate Studies and Research in Education (Associação Nacional de Pós-Graduação e Pesquisa em Educação Anped) on September 23 ${ }^{\text {rd }}$; the National History Association (Associação Nacional de História - Anpuh) on September 26 $6^{\text {th}}$; and the National Council of Physical Education (Conselbo Nacional de Educação Física - Confef) on September $28^{\text {th }}$.

In parallel, Brazil's main social media "broke the internet"2, with thousands of posts referring to these changes, whether in short texts via $\#^{3}$ on www.twitter. com.br, in images as on www.instagram.com, videos posted on www.YouTube.br, or through a combination of texts, video and images, as on www.facebook.com. These elements indicate the representation that these media have in the Brazilian social context. One data set about this condition is the number of users that they have in Brazil: Facebook now has 129 million users in Brazil; Instagram, 35 million; Twitter, 33.3 million; and YouTube, 82 million (Ribeiro, 2019). These figures make these media particular extensions and daily activities, even in terms of discussing

1 The last version issued by the Ministry of Education and Culture in April 2018 included greater structure related to the directions for the field of mathematics and languages, specifically the curricular component Portuguese Language. Thus, the other fields and their respective curriculum components will still have to await the elaborations of the curricular of the other levels of education.

2 This is an expression used by people on the internet to describe an internal movement involving intense sharing, likes and comments on the internet about a single issue.

3 Hashtag is a composite of a keyword, or of a single word, which is preceded by the number or pound sign (\#). Tags signify etiquettes and refer to relevant words that, associated to the symbol \#, become hashtags. This type of marking, used on social networks and in other media, serve to associate information to a topic or discussion. Generally, the hashtags become links that can be indexed by search tools (Redação, 2016). 
high school education reform, and they constitute emerging spaces for diffusion and sharing of information, ideas, perspectives and possible research fields, which keep the discussion about these changes up to date and revised.

They provide visibility to questionings and reflections from the practitioners of daily school activities, given that among the different uses and consumptions (Certeau, 2002), the media can be considered tools for the diffusion and sharing of ideas, opinions, facts, data, criticisms, frustrations and perspectives. They also evoke a dual understanding of the space and time of daily life: the first is presented as an extension of the place practiced and the second as the place itself to be practiced. That is, they receive narrative components whose values are spatial syntaxes, which indicate a configurative process established by social connections and relations, expressed by constant exchanges, migrations, movements, and passage from a space or from one space to another.

The internet is a place that extends through a movement of interconnection, and the relationship between the real and the virtual no longer exists, there is only one place. For Levy (1999, p. 47), "the virtual from a philosophical perspective is any deterritorialized entity that is capable of generating various concrete manifestations at different moments and certain locations, without, however, it being tied to a particular place or time".

In the case of the social media as experiences of this virtual, they can also be understood as interfaces that allow interaction through texts, sounds, images, videos and even reading, which allows the maximum connection of the ordinary and the virtual worlds (Levy, 1999). Poissant (2009), meanwhile, understands that one of the fundamental structures of the interfaces is to allow the transfiguration of the spectator subject into an actor, connecting humans and machines. To this end, the author uses the term "artsmedias", which transforms the interfaces into types of conductors and modifiers of daily tasks. She mentions a possible artistic aesthetic, in which people can be writers, columnists, artists, painters, filmmakers, and musicians.

In this way, what are the discursive practices undertaken by the subjects who have discussed high education reform in the cyberspace of the social media? Who are the subjects who are practitioners of these discussions? What are the narratives assumed and promoted in the content of these discourses? This study seeks to problematize the ways in which the reform of high school education has been addressed on the social networks with the most users in Brazil.

\section{METHODS}

Virtual space, or cyberspace, has become a place of unequaled opportunities for the realization of new ethnographies, whether by investigating specific groups who participate in blogs, or by passing through the social networks until reaching specific sites about a certain issue.

For Aguiar (2007, p. 4), "digital or online ethnography involves the observation of subjects in their process of construction of perceptions and behaviors in the social relation on the network". This methodological line began to be explored with the rise of virtual communities, in the late 1980s. 
The transposition of this methodology to the study of communicational practices mediated by computer receives the name of Netnography, or virtual ethnography and its adoption is validated in the field of communication by the fact that many objects of study are located in the cyberspace. (Montardo and Rocha, 2005, p. 1)

Nevertheless, it is important that it definitively involves a very particular scientific involvement, to the degree that it is possible for the researcher to become invisible, or that is, to see without being seen, (a) not interfering, in principle, in the dynamics of the interaction observed. It is this participation (even if it is not visible) in the group that can allow grasping aspects of that culture, allowing the development of a dense description, which requires a detailed understanding of the meanings shared by its members and of the network of meaning in question (Braga, 2006).

In this sense, Kozinets (2014) suggests four practical actions that can revive basic procedures of methodology specific to the transposition of ethnography to netnography: cultural entrée, collection and analysis of data, research ethics and checking of information with the members of the group.

With these considerations, a netnography was conducted on the interfaces of the social networks Facebook.com, Instagram.com, Twitter.com and YouTube.com, using as a source the narratives (textual, imagetic or audiovisual) presented by Brazilian social actors who discussed and/or made statements about the provisional measure promoting high school education reform (MP No. 746) in these online spaces. Given the particularities that involve each one of the sites and their material productions, as well as those recommended by the netnography, it was necessary to establish some exclusion and selection criteria: the first involves the clarity around the formulation of the research question, because it would not be viable to analyze everything that was posted over time about high school. For this reason, a shift was made to high school education reform, which in addition to its historic marking, would have a lower volume of data and present other information about this phase of schooling. The second element concerns the temporal scope of the researcher's incursion into the field. In this regard, we only consider posts made from September $22^{\text {nd }}, 2016$, the date of presentation of MP/746, until February $16^{\text {th }}$, 2017, the date that Law 13.415 was sanctioned. The third element refers to the cultural entrée, for which an account was created on each one of the networks selected, as can be seen in Figure 1.

The descriptors $\mathrm{mp}$ ensino médio (provisional measure high school education), \#ensinomedio (high school education), \#reformaensinomedio (high school education reform) and reformaensinomedio ((high school education reform) were inserted in the search tools in each one of the social networks, as seen in Figure 2.

Then, given the recommendations by Kozinets (2014), the process of observation and document storage was conducted, maintaining the time period between September $23^{\text {rd }}, 2016$ and February $16^{\text {th }}, 2017$. Since the discussions and participations of the users revolved around the provisional measure, we decided not to formulate interviews or even generate discussion themes with new postings, but rather to analyze the material already produced, denominated archival data. Thus, the daily and extensive accompaniment was maintained for nearly 5 hours per day observing the discussions and interactions of participants on the social networks 


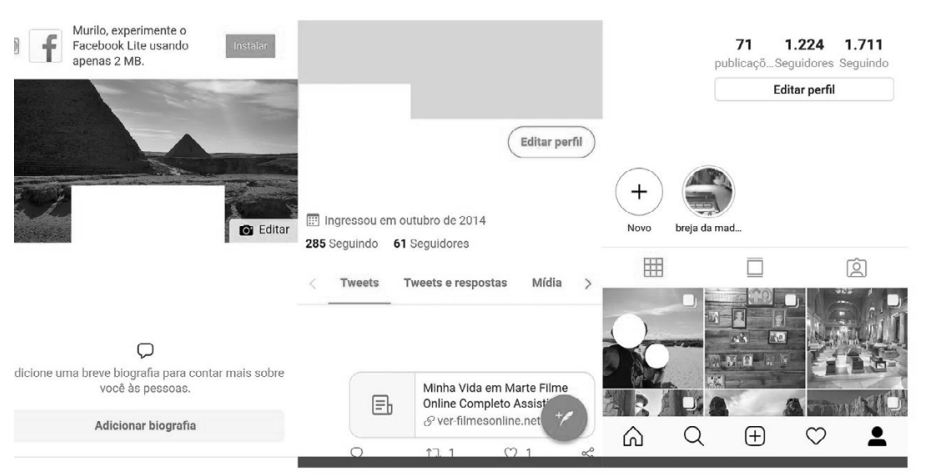

Figure 1 - Accounts created to enter and interact on the 3 social media platforms.

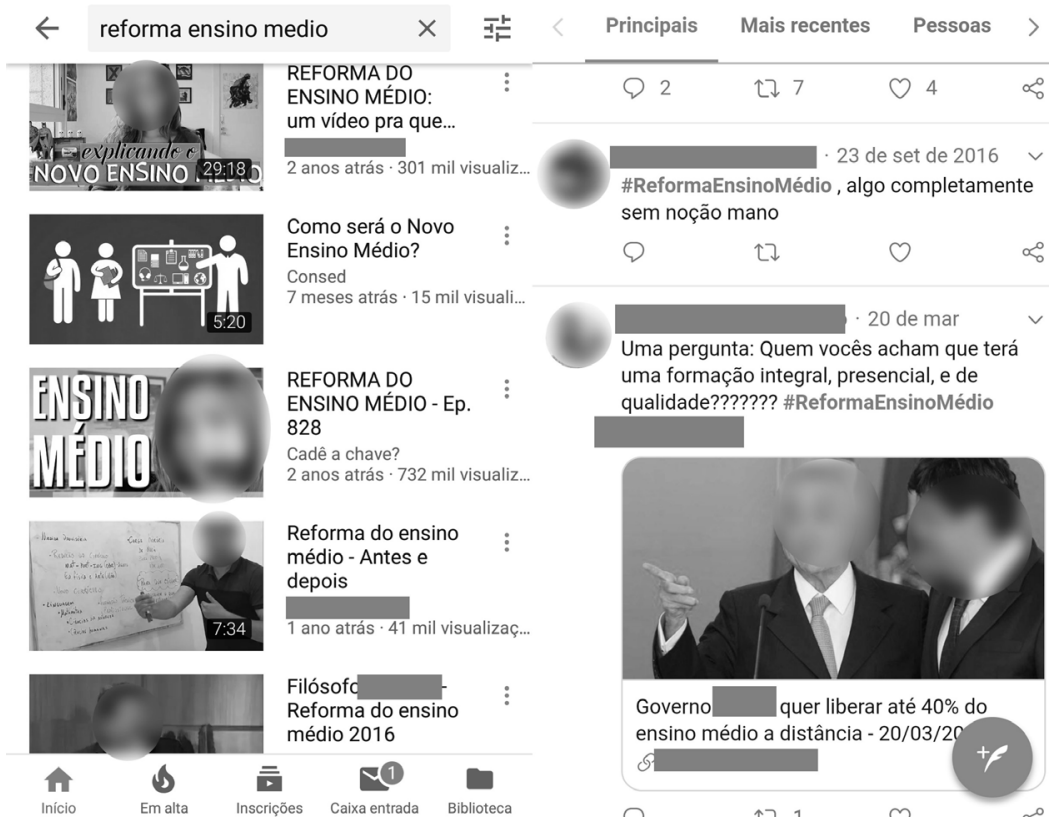

Figure 2 - Example of the search template and some of the results generated by the descriptors on YouTube.

analyzed. It should be emphasized that after logging in, none of the pages have any pre-requirements or request authorization for accessing information, comments, and posts. Thus, interactions like those in Figure 3 were analyzed, according to each one of the social networks.

On Twitter, people can interact by producing an initial tweet, which in turn allows interaction with other users, whether by liking, with a heart symbol; retweeting using the figure in the center; or they can participate by writing commentaries using the balloon figure. It should be noted that in each one of the platforms analyzed there are particular interfaces that optimize this type of intragroup com- 
TWITEIRA

O Plenário da Câmara concluiu a votação da reforma do ensino médio (MP

746). Desde que o... fb.me/7qSliuwGC

Q 1 切 1

Fonte: extraída do Twitter.

Figura 3 - Modelo de interação dos participantes, exemplo do Twitter.

munication, but maintain this basic presumption between initial post, whether by video (YouTube), image (Instagram), combination of text and image (Facebook) and other interactive participations of the other members.

The following phase was dedicated to the interactive analyses and interpretations of the material collected. For Kozinets (2014), a researcher should strive to understand the participations of the members in articulation with a discussion context. In this case, the decision to select archived data helped to maintain the authorship and subjective intentions produced by the subjects of these networks. Another important element that is considered in the ethnographies refers to the credibility of behavior and actions of those studied considering the presence of the researcher. This issue did not arise, because the sources were not produced by induction by the researcher, but by the representations and interests of the participants of these social media.

Based on these specificities presented by the interactive interfaces of each social network, the reading and capturing of the narratives produced in their entirety was initiated. To do so, in each one of the pages analyzed, we converted the textual content into Portable Document Format (PDF), as seen in Figure 4, to improve the analysis process.

This action provided the following amounts per page: Instagram, with \#reformaensinomedio yielded 50 pages with one post each; Facebook, with \#reformadoensinomédio generated 15 pages with 3-4 posts per page, while on \#reformaensinomédio, 28 pages were produced with 3 to 4 posts; Twitter with \#mpensinomédio had 5 pages with 7-8 posts per page and \#reformaensinomédio 4 pages with 7-8 posts per page. The procedure on YouTube was different: first the videos with the most views were selected and, after being analyzed, the comments produced were extracted from each one , providing about 20 pages with 10 to 12 posts per page.

Kozinets (2010) indicates that, when facing an extensive volume of textual material collected, the researcher can use qualitative analysis software for semantic recognition and organization. Thus, Iramuteq $\mathrm{R}$ was used, and all of the material collected was inserted in the software's interface, which produced a Word Cloud ${ }^{4}$ and a Similarity $\mathrm{Graph}^{5}$ composed of the most reccurrent textual on the platforms studied. This study was approved by the Research Ethics Committee of UFES, CAAE No. 78655917.2.0000.5542 and Opinion No. 2.364.717.

4 Lexical analysis that occurs based on a grouping and organization of the words as a function of their frequency (Camargo and Justo, 2013).

5 This is a type of analysis that is based on graph theory that allows the identification of co-occurrences among words and their possible connections (Camargo and Justo, 2013). 


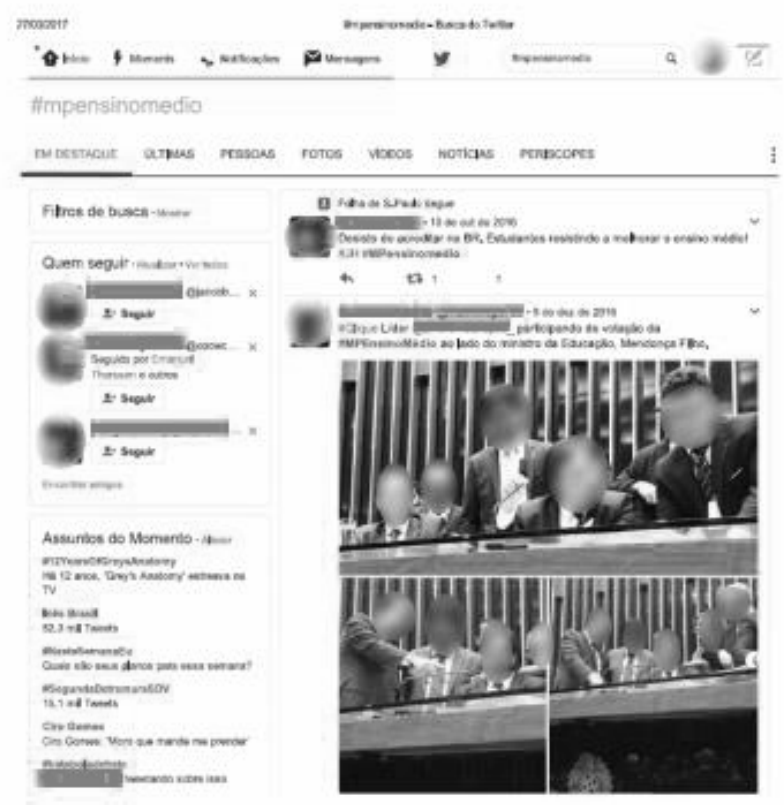

Figure 4- Example of an image converted from the virtual platform to PDF.

\section{ANALYSIS AND DISCUSSION OF THE RESULTS}

To expand the analysis procedure, complete textual fragments were extracted from the interactions of the subjects on social media. This action was conducted to situate the words produced by the software, as seen in Figure 5, in the context of the integral narratives of the participants. As a selection criteria, it was decided to use those with the most comments or likes, which were generally located on the first pages of the platforms, given that:

A netnography observes not only the words used in social interactions, but also the elements of the forum, the characteristics of the communicator, the languages used, the history, meaning, type of interaction. It examines sources, spacing, symbols, texts, images, photos and videos. (Kozinets, 2010, p. 6)

According to Kozinets $(2010,2014)$, it is important to articulate the actions of the subjects in a given context, mainly to locate the meanings expressed in the textual narratives produced. It was with this perspective that the terms produced by the word cloud were extracted. The textual arrangement of the terms has more meaning when it is articulated with their intertext. To do so, the similarity graph was prepared, according to IramuteqR, represented by Figure 6 .

In both the word cloud and the similarity graph, the terms ensino médio (high school education), reforma (reform), governo (government), escola (school), professor 


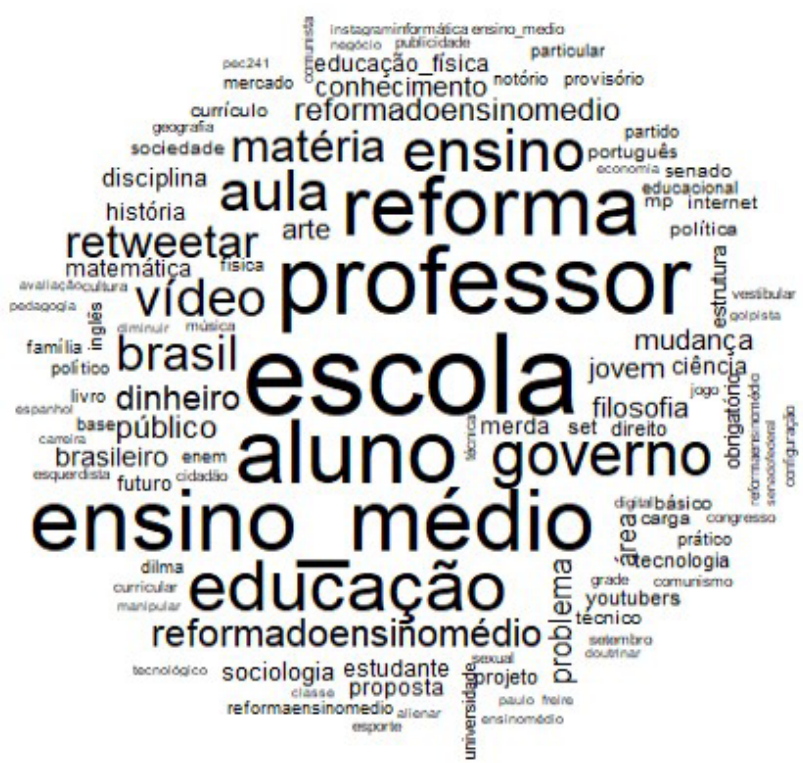

Figure 5 - Word cloud based on the recurrence by term from Iramuteq $\mathrm{R}$.

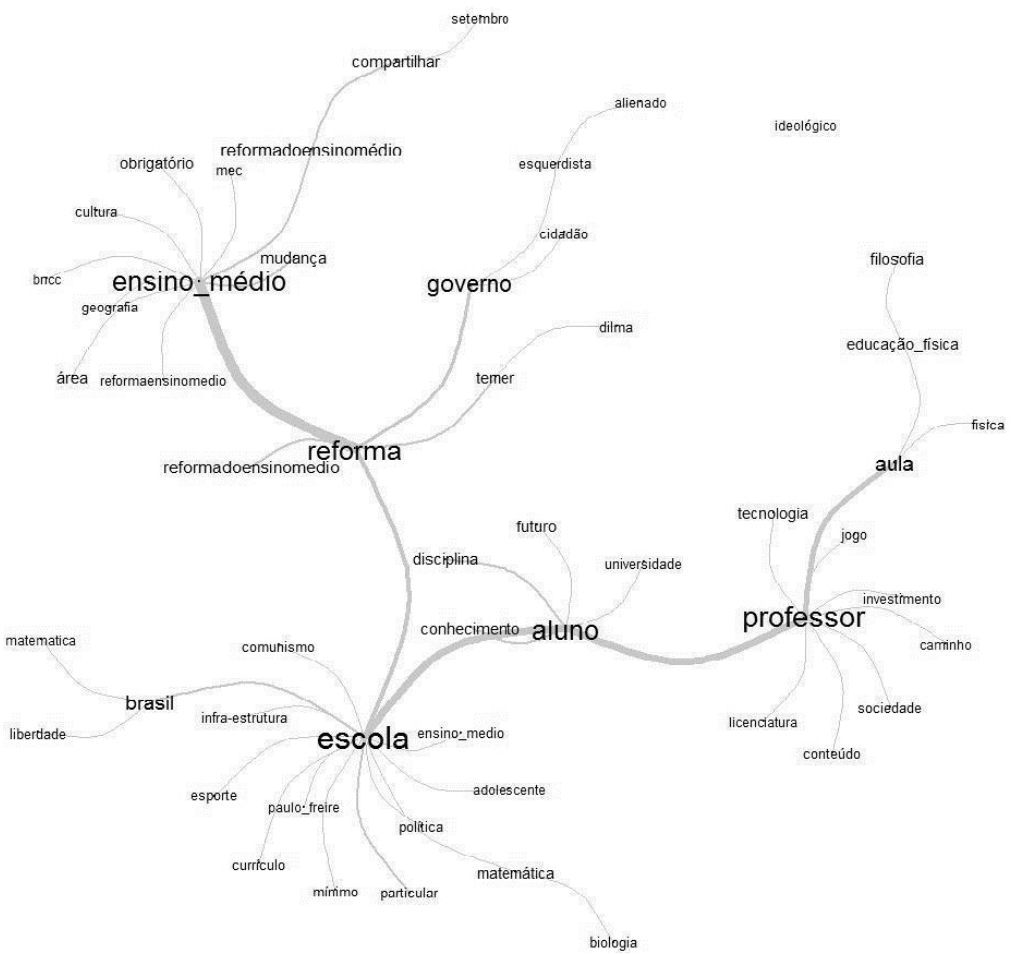

Figure 6 - Similarity Graph of the relationship between the terms and the narrative context. 
(teacher) and aluno (student) express and represent the central issues involved with the changes in this educational phase. By analyzing the terms from right to left, identifying the semantic elements that surround the main terms in Figure 6, the sociopolitical meanings that influence the consequences of the curricular rearrangements for high schools can be seen.

Given the particularities of these sources and the actors that produce them, it is possible to understand that this reform makes high school a historic object in movement. For Bloch (2001), to practice historic research is to go beyond the traps of time, which may be represented chronologically by the expressions past and present. For this reason, in this context it is inferred that high school education has the condition of a continuum, that is, it is presented diachronically in a temporal in-between space.

Thus, given that which the sources indicated in the period of observation, combined with the tracks and indications (Ginzburg, 2002) left in Figures 5 and 6 , the results were organized into two categories. They are:

- sociopolitical indicators of high school education in the online context;

- social actors on the online space.

\section{SOCIOPOLITICAL INDICATORS OF HIGH SCHOOL EDUCATION IN THE ONLINE CONTEXT}

One of the central points of the reform that was observed is related to the meanings of the purposes ${ }^{6}$ attributed to this phase of basic education. The individuals constantly discussed and at times compared the models and places that high school has occupied in Brazil, with what was proposed in this provisional measure. These elements can be exemplified in some of the textual fragments collected.

Twitter user 10: I agree so this way the poor don't have to occupy a place in college just because of the quotas.

Twitter user 13: "\#NovoEnsinoMédio [NewHighSchool] wants to educate people for the market. No need to know how to think and to be critical. Literally don't think, work".

YouTuber 03: The question is, the new high school does not have this function of contextualizing students with the world around them (I always thought this was important and applied it in my classes).

YouTuber 17: To finish high school ready to work in the market for the poor, college entrance exam for the rich!

YouTuber 18: my college entrance exam will only have the subjects that I chose to study in high school too? hahabaha.

6 Etymologically, purpose (finalidade in Portuguese = finality) refers to the end to be reached. In this case, it is understood to be the learnings that are (re) appropriated by the students upon completing high school. The responsibility for which would be the state and public educational policies. 
Instagrammer 11: This project is marvelous; it will encourage young people more in their future careers and decrease school abandonment. What is most common is students skipping a boring class because it has no interest for [their] lives, but imagine if they only take classes that will help them in life. There will be more students in school than in the streets vulnerable to drug dealing, not to mention that the revolt of the teachers shows how unprepared they are.

For Kuenzer (2000), the presumptions that have led this phase of education to be constantly at the center of discussions about basic education are related to its purposes in the Brazilian school project, historically alternating between: offering professional education with a character of terminality or offering a preparatory education focused on continuing studies in higher education. The latter category also includes an opportunity for segmentation based on the field of higher education that the student intends to enter.

Thus,

Throughout history, high school is constituted in a socially constructed absence, on the one hand, by the lack of concern for bases for expansion of scientific, technical, and technological production and on the other for the destination of the broad segment of the population to the option of education predominately for simple work. Thus, quantitatively and qualitatively, high school did not become established as a development strategy or an indispensable step in the education and development of the majority of the young population. (Brasil, 2013, p. 3)

These structural archetypes of high school can be better understood by considering the historic, political, and ideological changes in the society of work. The concept of work changed with the logic of capital with reverberations for the ideological concepts of education, which made it a social practice that mediates the process of production, that is political, ideological, and cultural. Thus, as the final step of basic education, high school becomes strategically shaped in the relationship between work, culture and scientific knowledge, to meet the socioeconomic dictates guided by principles of the educational act based on ethical-political structures and not technical-didactic or methodological ones related to learning (Frigotto, 2012).

The possible changes to be realized in Brazilian high school education remain focused on the dimension of curricular reorganization and the role of the government agencies. And these agencies, by establishing the routes to be taken by Brazilian education, have opted, in greater or lesser extent, for a neoliberal line of education. As Moreira (2000, p. 109) affirms:

Numerous studies have criticized the recent educational reforms promoted in much of the world, highlighted by efforts to reformulate curriculums of the different levels of education. Using various theoretical references, the analyses warn, among other aspects, that the proposals are inserted in a universal movement to restructure educational systems in Western welfare societies (Carlgren 
1998), playing an important role in the legitimation processes that in these societies (Popkewitz, Pitman and Barry 1998), express the conservative interests of right-wing groups that seek to apply the laws of the free market to schools (Apple 1993; Whitty, Power and Halpin 1998) and are made concrete in the global practices that involve producing systems of inclusion and exclusion (Burbules 1998). They also emphasize that the curriculum changes are usually accompanied by attempts to implant a national system of evaluation and changes in the arrangements by which students are educated and improved.

Reaffirming one of the meanings of ethnographies, it is necessary to locate the textual, imagetic, and audiovisual compositions produced by these social media in the broader educational sociopolitical situation. One of the ways to do this is to use official documents, given that these sources are manipulable places of power that embody desires for "political making believe" (Certeau, 2002), in which the school is promoted with conveyed ideas.

In the National Curriculum Parameters for High School (Brasil, 2000), it is possible to find indications that consider the need to articulate school knowledge with the transformations taking place in contemporary society, highlighted by the consequences of technological advances. To do so, as the final step of basic education, high school should assure that students have competencies that will allow them to produce knowledge, live their social lives fully and participate in the world of work. Thus, the curricular components were organized in fields to which the objects of study were approximated. The intention was to allow students to acquire knowledge with scientific foundation in its epistemic diversity, from mathematics to the human sciences.

Meanwhile, in the preparation of the National Curricular Guidelines (Brasil, 2013 $)^{7}$, the purposes of high school education are defined according to the principles of work, science, technology and culture, to assure a broad human education. To do so, the knowledge presented related to work should be based on a perspective of education and development of individuals, as being inherent to human transformation of nature, and the element that is basic to the others. The technological and scientific aspects refer to the human intervention in the material environment, that is, they design and produce forms of knowledge that contribute to individual and collective vital activities that organize reality. Culture is understood as the human activity that articulates a set of representations, symbols, material expressions, and dynamic modes of socialization that constitute the way of life of a given population. High school and its curricular components should assure such knowledge.

7 Document produced in 2013 and which became practically refuted with the creation of the National Common Curricular Base which would support the path of this reform. It should be said that three years separate the documents, which raises the following reflections, was there time for the document of 2013 to become outdated? Who are the social actors responsible for the production of each one? What continuities and discontinuities will be realized? These are elements that have at their aegis the political reconfigurations that took place in Brazil in recent years. 
Among the narratives are noted those that refer to the limitations that this reform presents. One of them considers that the modifications to the curricular composition are not sufficient for the development of high school education, because it is necessary that other actions be articulated, ranging from structural improvements at schools to the resolution of social and economic differences that directly affect access, attendance, and continuity in schools. As can be seen:

YouTuber 19: This video was not very impartial, because it only spoke as if it was something good, in fact the project is great, so much so that countries with high levels of education (like South Korea) made this reform. However, it took more than forty years, I am not saying that more than a decade is needed, but one year is very little, much more so with a country without a good school foundation.

YouTuber 20: The reform of High School Education should be JOINED BY A REFORM AT SCHOOLS, because no one will want to be SEATED in a HARD chair, for more TIME combined with the HEAT OF THE CLASSROOM AND BAD MATERIALS.

Twitter user 10: About \#novoensinomédio, [new highschooleducation], schools don't even have physical structures, so they decided to change education. Instead of improving other things.

YouTuber 07: What I think is that school should serve more as a preparation for life in general, instead of teaching things like Baskara and trigonometry, which someone is unlikely to use after finishing high school.

YouTuber 05: Ok, the curriculum can and should be improved. But it will have little effect in schools that are left to decay and teachers who are fckd... and poorly paid! They speak of the use of technologies when neither physical or virtual space is provided. Before altering the curriculum, they should provide quick, cheap access and to a large volume of data, for EVERYONE.

In terms of representation of the curriculum, Sacristán (2000) considers it as an interlinking of the cultural and pedagogical, whose function is to be a balanced praxis of educational action that involves interests and forces, affirmations, conflicts, counter-positions, and predefined roles that are in movement, which revolve around the educational system. Upon analyzing this process of curriculum composition, it should go beyond the perspectives focused on the selection and offer of contents: and understand how codes and practices are essential components. Codes function as political, social, epistemological options, as pedagogical or psychological principles and organizational criteria that intervene in the selection, ordering, sequencing and pedagogical instrumentalization of the curriculum for teachers and students (Sacristán, 2000).

Thus,

Curriculum is a praxis more than a static object emanated from a coherent model of thinking about education or the learning needed by children and youth, which is also not limited to the explicit portion of the project of cultural socialization in schools. It is a practice, expression, of the socializing and cul- 
tural function that a certain institution has, which regroups around it a series of subsystems or diverse practices, among which are found the pedagogical practices undertaken in school institutions that we commonly call education. It is a practice that is expressed in various practical behaviors. The curriculum, as a project based on a constructed and ordered plan, makes a connection between certain principles and their realization, something that must be proven and that in this practical expression fulfills their value. It is a practice in which a dialog is established, in a manner of speaking, among social agents, technical elements, students who react to it, teachers who shape it, etc. (Sacristán, 2000, p. 15-16)

Curriculum is not a reservoir of static knowledge, but a territory of dispute of knowledge that encompasses the epistemological plurality of the current world and the heterogeneity of the social subjects that arrive at schools. To think of other curriculums requires recognizing this plurality of knowledge, recognizing the epistemological plurality of our world, and specifically the epistemological and cultural plurality that reaches the schools with other teachers and students.

For Krawczyk (2009) and Kuenzer (2000), high school curriculum has always been a field of dispute between different social projects and professional groups, whether through conflict over a portion of the socially produced knowledge, or through the potential to expand insertion in the labor market. Those that defend the removal of these components consider them to have little use for the characteristics and demands of the current labor market.

Moreover, in the context of the interactions and productions of the subjects in these media, it is possible to verify that the relationship between finalities and curriculum of high school education are constantly tied to disciplinary knowledge. The research subjects consider that these structures are responsible for providing students with knowledge that is essential to practicing their daily lives. Thus, one group considers that by denying students access to some curriculum components, of the 13 that now compose high school education, this reform will produce setbacks, such as: preventing the plurality of knowledge offered by these disciplines.

As can be seen in the transcriptions:

YouTuber 29: This MP is an attempt to trash education even more. As well explained in the video, we are not Portugal, Germany, or such, not to mention that our schools have poor infrastructure.

Twitter user 14: This high school education reform makes no sense! Physical education should be optional, history and geography mandatory.

YouTuber 42: I do not agree with removing the requirement for any of these subjects, first, because the number of hours given to them has always been little, as it should be. What makes them outdated and not interesting to students, is that they aren't addressed by prepared teachers, which will only worsen with the Provisional Measure given that from now on, the teacher will only need to have "recognized knowledge" and no longer specialized education in a field. 
YouTuber 23: Children won't know how to deal with these issues if they're not taught from an early age. Why do you think older people are so homophobic and a bit sexist? YouTuber 25: I finished high school without knowing Baskara's formula (Yes it was taught it, but "I" did not learn it)... However, this did not hamper me in any way, the clients that I serve at McDonalds don't care about it.

Instagrammer 2: about art, I think it's not necessary, I prefer music, or computer labs, or an English class with American teachers, this English taught at school is shitty af....\#minhaopiniao. [\#myopinion]

From this perspective on the type of knowledge that is relevant and irrelevant at the high school level, this curricular flexibilization allows grasping the reasons for the opportunity to reduce the mandatory nature of curricular components for physical education, arts, philosophy, and sociology and affirm the requirement for mathematics, Portuguese language, and foreign languages.

Another structural change in the curricular organization involves the gradual increase of required hours, to expand the offer of day-long high school. From the National Curricular Guidelines of 2013 to the proposals for the Law for Guidelines and Bases of National Education, a version that changed Law No. 13.415 in 2017, we see: "II - For regular high school, the minimum duration is three years, with a minimum total of 2,400 hours, with a reference of 800 hours per year, distributed in at least 200 days of effective school work" (Brasil, 2013, p. 188).

This change was also discussed on social media:

YouTuber 21: I don't really get what they want with this fulltime classes thing. I study at a daylong public school, we have ten classes per day and what I see most is students sleeping on the bench or in the middle of class working on the college prep class activities (because it's ridiculous to think anyone can pass the college entrance exam without having physics or biology classes), there are students who also work. We don't even have time to breathe and we still have precarious classes. Some teachers spend weeks without presenting a new subject.

YouTuber 16: I am from Pernambuco ${ }^{8}$, and the only thing that really happened was that students became saturated in school, teachers worn-out, students locked up in terrible school conditions from 7:30 to 17:00 (Bad food, lack of water, lack of resources like white board markets, projectors, water fountains, fans and other things) which lead to a lack of time and interest on everyone's part.

Note that among those who criticize this point of the reform, certain limitations, mainly of a configurational and organizational nature, are attributed to this increase in class hours. One of them concerns the way in which other school levels are organized, because full-time schools are not a reality for a significant portion

8 This narrative presents indications of the birth of the Instituto de Corresponsabilidade pela Educação (ICE) which has contributed to the approximation between public-private and structural changes in the school project, like the fulltime schools and school configurations with business principles and the vision of a market economy. 
of them. That is, how will subjects in schools react behaviorally and subjectively to this timeframe when it is only found in the last 3 of the approximately 14 years of basic education? Moreover, they question the curricular compositions that will be implemented, as it is possible that there will be more overlapping, and repetition of contents and actions promoted in the other school phases. Given that expanding school time in the curriculum cannot only be related to an increase of class hours.

These sociopolitical indications are confirmed in the emphasis of the term Governo (government), in one of the central axes of Figure 6, as it reaffirms the political nature and influence in the educational context. This is repeatedly expressed in the narratives analyzed, and at times accompanied by nouns from the ideologies considered to be right and left ${ }^{9}$, whose expression has been highlighted by an apparent partisan nature of Brazilian schools, mainly in the form of teachers who allegedly indoctrinate students with a leftist education. This has also been one of the arguments of the group who defend the "school without political parties" movement that is based on the narrative that there is leftist political party indoctrination in classrooms. Nevertheless, there are no effective data or studies to confirm these presumptions.

Indications of this debate can be captured in the passages below.

YouTuber 27: They removed sociology and philosophy from the high school curriculum because they know that people who are informed and have a critical sense overthrow the state.

Twitter user 64: Good day my right-wing physical education teacher friend. You did not believe there would be a high school reform and you supported the coup [as the 2016 impeachment of Worker's Party President Dilma Rouseff is referred to]. Good luck to you.

YouTuber 24: It is not common for them to speak about this at the Federal Institute where I study. The humanities like sociology and philosophy speak more about politics, etc. Saying that we cannot let the politicians influence us, etc., always to look at both sides, etc.

YouTuber 26: Do you really think that the philosophy class given by the state would create critical minds to defeat the state? The class is given by the state. If you want to have a critical sensibility, spend a day on the internet watching philosophy and you will learn much more than at state schools that don't even have teachers trained for that.

On the other hand, for Certeau (2002), political ideologies must be inserted in the logics of the place that produces and reproduces them in activism that is organized around techniques of making people believe, organized around a Belief,

9 A reading of the textual compositions reveals that the subjects who consider themselves to be on the right identify themselves as such based on a denial of universal rights, and they give secondary importance to the affirmation of liberal ideologies. On the other side, people who consider themselves to be on the left identify themselves as such because they defend the idea of a state that provides polices for equality and access. 
in which resides a speaking in name of a reality and the capacity of the discourse authorized by a "reality" that is intersected with the media narrative - an institution of the real - which supports the organization of practices, that is, political credibilities to make people believe.

This speaking of a reality can be seen in the narrative disputes in the discussion environments on the platforms, marked by arguments of the antitheses between projects for schooling that combine the format of high school education and the type of knowledge to be shared.

Some posts intensify the debate over the process of curricular change initiated during the Dilma government, discretely expressed in the words of President Dilma Rousseff and then President Michel Temer, found in one of the ramifications of the axis Reforma [reform], in Figure 6.

YouTuber 22: This reform had been planned by Dilma, Temer only signed it. There are good things in this initiative, such as classes focused on the course that the student will choose in college (Languages, Nature, Humanities, and Hard Sciences) but the main thing is to remove the Cultural Marxism from the curriculum and from the methodology of teaching subjects, mainly the human sciences, which are completely tilted to the left, and must still be done.

In this way, instead of analyzing the impacts of the reform, the arguments are aimed at contradicting the group that supported the then president and that now criticize this change with the same bases; or, to use an expression from one of the internet users: "Dilma's group is full of "mimimi" or recalque [repression]"10.

Another point of the political issue that the medias analyzed present involves how the posts serve as tools to illustrate and promote what is being carried out. This is seen in a real-time post with a photo on Instagram and Facebook, made by a federal senator as he participated in discussions in the Commission of Education about the reform, or one with the presence of the minister of education in the federal Senate, who was accompanying the vote in a mixed commission, thus confirming one of the uses of social media, that of interlocution. In this case, the media offer these representatives proximity to and interaction with the electorate, even if some have assistants to do this.

The senator's photo was accompanied by the following caption:

Senator of the Republic on Instagram: \#ReformaEnsinoMedio[HighSchoolRefo $\mathrm{rm}$ ] Listen everyone, at this moment the mixed commission that will debate high school education reform is being installed. I would like to invite you to contribute here on the networks with opinions about the issue. We will also hear from teachers,

10 "Mimimi" is a pejorative reference to constant complaining by someone or by groups of people. "Recalque", - which literally means repression or a stubborn rejection - refers to disdain or disrespect for a certain position or action simply because it is contrary to that which a person considers significant. 
parents, and students from Espirito Santo [state] so we can arrive at a new high school education that is suitable to our needs. I am counting on you!

Figure 7 was an image posted on Instagram that depicts in a significant way the polarization over the political issues that involve the Brazilian situation, whose consequences are expressed in the reform of high school curriculum.

Instagrammer 1: This cartoon is another proof that politicians and parties never think of the people or the country, but rather on their own personal projects and power. It is not important who created [the policy], what is important is whether it will modernize education or not. Not to mention that the project will still undergo a long discussion with specialists. Nothing is decided, just a small group wanting to stir things up. Because even many educators support this initiative. I say "INITLATIVE", that is, it is only the beginning of the discussion.

Another argument that emerges from the narratives refers to the fragility of implementing a reform by means of a provisional measure [a presidential decree] and not a broadly debated legislative bill. The main counter argument made by defenders of the reform is the fact that the "failure" of high school education was discussed for many years and nothing consistent had been done, by these same entities, who now criticize the reform. It is also emphasized the articulation with the National Common Curricular Base, which leads to the study itineraries and consequently, the change in class time.

Instagrammer 2: There is a big difference between proposing and shoving DOWN ONE'S THROAT! You in the press should be concerned about carefully analyzing the proposal to see what it really means...I read the MP ... some things are interes-

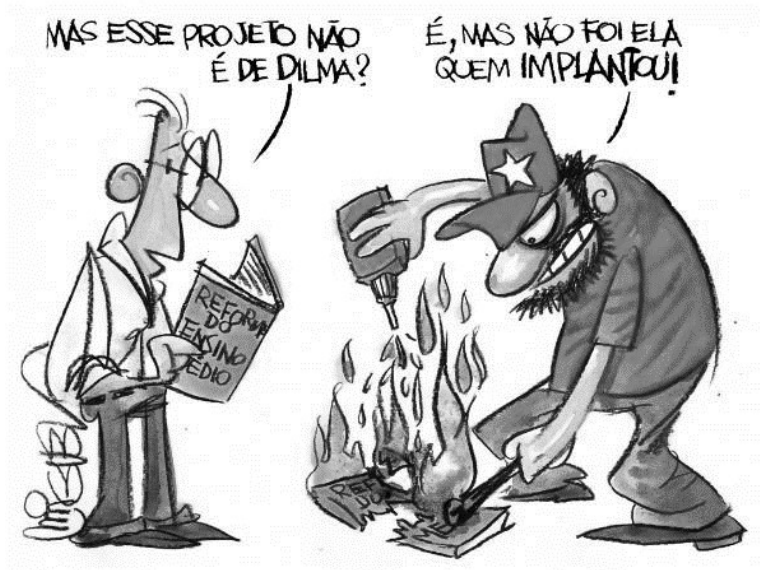

(JC) ic_pe

584 curtidas

jc_pe \#Charge \#RedesSociais \#JC \#JornalDoCommercio \#Recife \#Miguel \#REFORMAENSINOMEDIO

carregar mais comentários

vanderleinicacio Agora o JC é tendencioso? Hahaha!

belaadourado Eu só fico (-) (-); (-)

profvillar Tem muita diferença entre propor e empurrar GOELA ABAIXO !! Ate pq vcs da imprensa deveriam se preocupar em esmiuçar o projeto percebendo o que significa de

verdade li a MP . alcuumas coisas são

Source: Instagram.

Figure 7 - How do the discourses of the right and left understand curricular reform of high school education: [Man with glasses] But isn't this Dilma's project? [Bearded man] Yes, but she isn't the one who implemented it! 
ting, but most of it seems like an amateur proposal... you should be ashamed to present something without any logic...

YouTuber 30: Were teachers heard? No Were students heard? No Business? Certainly

The content of the narratives becomes much clearer when they are considered in the historical, social, and political moment in which Brazil is found. This reveals a context of political factions marked by narratives and counter-narratives of an aesthetic nature exemplified by Manicheist concepts of right and left. In this way, the discussions undertaken by the (re)appropriations of the subjects in online spaces are focused on the uses and consumptions related to incoherencies presented by a certain positioning, more than a broader analysis about the consequences of this reform.

Thus, the strategies and tactics used by these subjects are concentrated more on efforts to indicate the contradictions, incipience, and fragility of the argument presented by one side, more than in using possible structural and configurational analyses of this reform. It is thus presumed that the changes in sociopolitical bases that have polarized the Brazilian school project have led to the development of particular practices in the places where they are produced, which involve teachers, students, and researchers, in relation to this school context that is being reshaped.

For Han (2018) these structures based on discursive practices in cyberspace suggest a swarm- and school-type behavior constructed through an imaginary intensified by algorithms that indicate representative modes that approximate groups and people, in common perspectives and lines, which in turn influence behaviors, positions and arguments about specific elements. In this way, at first people are connected by fragments representative of the consensual themes, and then as the discussions and arguments are expressed, there is a unisonous process of expansion, reorganization and steering of apparent inflexible argumentative truths. The group, thus, produces noise, forms a swarm, producing a consonance of mass, with little or no coherence, but does not develop action in mass, because of the absence of a "we". They perform either as homos eletronicus, a connected being whose identity was psychically dissolved or homo digitalis, an individual who even in a group maintains their identity and uses the virtual as a space of reaffirmation and improvement of one's self and one's positions.

Thus, it is necessary to situate the narratives presented about high school education, highlighting the subjects who produce them in modes of doing and practicing the daily life of this educational phase, without in this way ignoring the sociopolitical forces that influence this space. In other words, it is necessary to give visibility to the webs that are involved in the constitution of daily life of high school, in the voice of the subjects themselves.

\section{SOCIAL ACTORS IN THE ONLINE PLACE}

Each social media has a specific interface, and individual must create an account or profile on each platform. After this procedure, specific forms of interaction, uses and consumptions are permitted among the participating members. 
These media develop specific environments in which discussions and comments are produced based on an originating theme that stimulates the posting of videos, images, or texts, or of the three elements in articulation. Generally, this generative theme is presented by a subject who has a certain level of intragroup representation.

These subjects are known as digital influencers, people who have and detain a certain level of representation and can influence tastes, interests, opinions and trends in relation to a certain group. This is how the first subjects who participated in the media analyzed were identified and it should be emphasized that each one of them establishes a specific nomenclature to present them.

The second group of individuals identified is that which interacts with the theme produced. In each one of the media, there are specific environments for this purpose. Thus, relatively to certain issues, the participants discuss, give opinions, disagree, fight, and agree.

It was found that the individuals who use YouTube, Facebook, and Instagram are mostly youth from 15 to 24 years of age, white, middle class, male, who live in mid- to large-cities. To access this information, the profiles of the all the research subjects were consulted and an effort was made to identify on their profile their age, profession and at times other photos that identify them. On Twitter, in particular, this profile of users is joined by politicians, mainly congressional representatives and senators, who are not in this age group, but who use the media as interlocutors and vehicles to promote their work to their voters. However, it is necessary to emphasize that this procedure does not guarantee the veracity of the profiles that are in the context of the discussion, given that the internet is permeated with fake accounts, the term used to designate people who create fictitious profiles.

Thus, it is possible to identify that the access to and the use of digital platforms is made mostly by young people. Moreover, a significant portion was found to be consisted of high school students. For Dayrell and Carrano (2002), Brazilian youth, should not be understood in a reductionist manner, by only considering age and biological indicators, but as a social category which is simultaneously a condition and a type of representation, influenced by economic, symbolic, cultural and historic elements.

In this sense, the social changes that have taken place, mainly with the advent of the digital in detriment to the analog, have contributed to the development of a generation of youth that has established different relations of uses and consumption, even by permeations of subjectivity, with this cultural artefact. The internet is part of what is denominated cyborg youth ${ }^{11}$, that is, the media and technologies can be understood as extensions of their subjectivities.

Sales (2014), also using the concept of cyborg, examines how the advance of computer technologies has allowed other forms of interaction of youth with others and their social contexts, and affirms that it goes beyond interaction to become a

11 This is a term used by Haraway (2000) to designate human beings who live at the frontier between machine and organism. A condition that produces cybernetic and or biotechnological beings. 
hybrid form of being in the world, in which machines and organisms combine. This can be perceived in how smartphones have become a new part of the body, a type of artefact that acts as an extension of the hands and allows a new opportunity for contact with the world, forming a digital ecology.

Moreover, the social networks accessed by smartphones are incorporated to the daily life of youths, even in daily school activities, as forms of social interaction, constituting spatial syntaxes of a continuum between the real and the virtual. In this way, the posts express elements of subjectivity produced by experiences lived in practiced daily lives, revising one of the functions of the social networks, that of granting autonomy and a place of protagonism to the avatar, as well as points of view, impressions, opinions and demarcations of social experiences, which instill in subjects another existential form of being, now in the condition of cyborg, that is, half machine, half human.

Upon plunging into the content of the narratives, it is possible to see the particular way that the actors understand the relationship of technology with schooling.

YouTuber 1: I completely agree with your opinion, I was involved in the school occupations [movement of 2016], and technology was one of the topics of the Brazilian Union of High school Students UBES, But the new high school education reform is nothing, nothing like that.

YouTuber 3: Exactly! Times have changed. And change is needed. And not only in high school, but in higher education as well. We need more contemporary Languages. To understand that the new technologies came to help, that THEY MUST BE part of the process and that it is crazy to fight this, because they are increasingly present. YouTuber 4: I think that this matter of introducing the digital world has to be something moderate. Because the first tools that we knew came coupled to our system.

Twitter user 1: The maximum technology that some teachers use in the classroom is a $D V D$, so they can show a film and then ask for a summary.

One of the most promoted issues of the reforms that explains the recurrence of the term aluno (student), in both Figures 5 and 6, refers to the outstanding place that these subjects will have, because they will all study in high school in the same way until the second year, when they are approximately 16 years old. After this first phase, they will choose one of the itineraries presented by the reform - languages, natural sciences, mathematics, human sciences or professional education - to study for the remaining year and a half. The National Curriculum Guidelines of 2013 had already indicated this possibility for curriculum organization by itineraries, "as long as the simultaneity of the dimensions of the work of science, technology, and of culture is guaranteed, and defined by a political-pedagogical project, meeting the needs, concerns and aspirations of the subjects and the reality of the school and its environment" (Brasil, 2013, p. 189).

The item that involves the protagonism of students in the choice of their itineraries is also discussed among the subjects on social media. 
Twitter user 3: The \#ReformadoEnsinoMedio in practice will be a mutilation of the curriculum. Most people will not have many options close to home. The \#Enem [college entrance exam] will be for the elite.

Twitter user 4: And you cannot choose 2 fields, or personalize your field: (\#reformadoensinomedio).

Twiiter user 5: "I choose what to know and exclude what is of no use to me". Does this student know that he is referring to knowledge about the WORLD? \#reformadoensinomedio Heads up!

Instagrammer 1: Human sciences will be optional???? Where are the people who know the history and mood of the country now???? They'll disappear!

These criticisms are also made due to difficulties that youth have with the choice criteria of these fields.

Twitter user 6: This \#ReformaDoEnsinoMedio is a big flake. Few youths at 15 really know what they want as a profession.

Twitter user 7: If I had stayed with the field of knowledge that I wanted when I was in high school, I would be frustrated until today. \#NovoEnsinoMédio.

These fields are described in the following passage from the Law of Educational Guidelines and Bases No. 9.394/1996, with additions from Law No.13.415 of 2017:

Art. 36. The high school curriculum will be composed of the National Common Curriculum Base and by educational itineraries, which will be organized through the offer of different curricular arrangements, according to the importance to the local context and the opportunity for educational systems, that is: I - languages and their technologies; II - mathematics and its technologies; III - natural sciences and its technologies; IV applied human and social sciences. (Brasil, 2017b, p. 26)

According to Brazilian law, the characterizing and structural aspects will be carried out with the implantation of the BNCC that will be responsible for defining the curricular compositions and organizations for high school. However, it should be emphasized that, on April $6^{\text {th }}, 2017$, the third version of the BNCC was approved and presented the curriculum for early childhood and elementary education. The part destined to high school was presented on April 2 ${ }^{\text {nd }}, 2018$ (Brasil, 2017a).

The arguments in defense of this composition by fields are based on the presumption that youth, when choosing their strongest interest and with it the curriculum components that compose it, will be motivated to stay in school and thus learn elements with which they have greater identification. They affirm that school abandonment in high school is often explained by the fact that students are not attracted to what is taught. Thus, in a simplistic manner there is a narrative flow that considers and blames the fragilities and limitations of high school, in its 
curriculum compositions organized around 13 curriculum components ${ }^{12}$ offered in 3 years.

Aspects that can be seen better in the transcriptions below:

YouTuber 5: They didn't take away physical education, they only gave people who don't care about this subject the opportunity to focus better on others. But it will still exist.

YouTuber 7: This new model in reality already functions in some public schools in Brazil, at least in a manner similar to those in the Federal Institutes. I had the opportunity to have studied at the Federal Institute of Rio Grande do Norte in the model of a technical school integrated to high school and I do not regret it.

YouTuber 8: I think that they gave this option to the schools, right? Because if it's like that I will clap these classes that were never important to me).

YouTuber 9: Some people think that history and sociology, are not subjects that make students aware of politics. This type of person believes in anything and that if you study history you will become a doctrinaire leftist, but they don't know that they are nothing more than unhappy and alienated.

One of the issues of the reform with lower consensus refers to the fifth area of knowledge, that of professional education, which removes the requirement for teacher accreditation and makes the teaching activity flexible, based on recognized knowledge, described in this way:

IV - professionals with knowledge recognized by the respective teaching systems, to teach the contents of fields related to their education or professional experiences, confirmed by specific degree or teaching practice in public or private educational unit or at private corporations in which they have acted. (Brasil, 2017b, p. 2)

About this issue, the following comment was registered:

Facebook user 1: Yes, this business that of a person having "recognized knowledge" is completely inadequate. As a university student in teacher accreditation in history, I am quite concerned with this. I worked hard to get into college to be a teacher, earn my diploma and ob my, now anyone can give classes? They just have to have a "notion" about the subject? That's not right!

Another subject that also has a central place in the discussions is the teacher, and the use of this term confirms what can be seen in the analyses, given that this individual is treated either as a hero, or as a villain; either as a central actor, or as a secondary subject in the project for schooling and high school education in Brazil.

12 They are: mathematics, physics, biology, chemistry, geography, history, philosophy, sociology, English language, Portuguese language, literature, Arts and physical education. 
YouTuber 10: Teachers pretend that they teach, and students pretend that they learn. The main objective of the students is only to pass, and they are not concerned with learning.

YouTuber 11: Any class would be better if it had two teachers (less monotonous) and the pauses were removed as if they were edited. And also if we could pause them to understand something without 28 crazy people talking in the background.

YouTuber 12: But the blame is not only on the teacher, think about it, teachers are poorly paid, have no incentive to happiness, that's why they are like that, if teachers were respected and well paid, your teacher would be less cranky.

YouTuber 13: Ok, the curriculum can and should be improved. But it will have little effect in schools that are falling apart and teachers who are not respected! This resolved, and given a decent pay to teachers, we would have a minor revolution in education.

This polyphony of narratives and arguments contributes to the discussions about the resonances that this reform will have in the Brazilian schooling project. Although there is no consensus, they express significant questions about the place of high school education at the heart of basic education. We can also reflect on to what degree the narratives and counternarratives based on aesthetic analyses of an ideological nature represented by right and left, supported by Manicheist elements, have hidden a larger discussion about the impacts and reverberations of a structural, configurational nature and the influence that these changes can have on the knowledge/doings that involve Brazilian high school education.

\section{FINAL CONSIDERATIONS}

Finally, according to the issues raised, it is possible to conclude that the reform of high school education is also present in the discussion on social media analyzed, initially, based on provisional measure MP No. 746 when it was sent to Congress, and later on Law No.13.415/17. The main arguments of those who defend this reform in cyberspace are based on the associative representation between failure of high schools and the number of subjects taught, which is considered to be excessive and that apparently contributes very little to the social life of students. It is possible to say that among the social media analyzed, YouTube is the main analytical source, because of the quantity of textual production as well as the interactive possibilities that the media offers. This may be a consequence of its interface, in which a video is produced and the other members have space to comment on the issue.

It can also be said that the central themes addressed in all the medias refer to a conception of a political nature, in which the arguments that defend the reforms do so based on a liberal conception, considered to be from the political right, and more closely linked with current market interests. That is, they affirm that schools should share a type of knowledge that allows complete insertion in the labor market. The arguments against the reforms are considered to have a leftist bias and affirm 
that the state has increasingly removed itself from the commitment to offer quality public education that would help mitigate the social inequalities of Brazilian society.

With this polarization, the central discussion is no longer about high school education, and comes to be over political ideologies, which makes the reform an expression of these positions. Thus, it becomes difficult to understand the impact that this reform will provoke on the daily life in high school. Nevertheless, some points can be highlighted, based on the comments, for example, the impacts that the $\mathrm{BNCC}$ will have on the quality of the structural element of high school education.

Some questions are pertinent: mainly those that refer to structure and function of a school in the new molds proposed. For example: what criteria will be considered when students chose the course to follow? Imagine if 200 students from a school reach the second year when they must choose an itinerary. If they all choose the same one, will the school determine how many students can take each itinerary? By doing so and students cannot choose their first option because they do not have good grades, wouldn't there also be a risk that students will drop out? In relation to access to higher education, will the evaluations for entrance only be based on knowledge about the field that the student chooses? And if students choose professional education and at the end of the course, decide to go to college, what criteria will be adopted?

\section{REFERENCES}

AGUIAR, S. Redes sociais na internet: desafios à pesquisa. In: Congresso Brasileiro de Ciências da Comunicação, 30., 2007, Santos. Annals... Santos, 2007.

$\mathrm{BLOCH}, \mathrm{M}$. Apologia da história ou o ofício do historiador. Rio de Janeiro: Jorge Zahar, 2001.

BRAGA, A. Técnica etnográfica aplicada à comunicação online: uma discussão metodológica. UNIrevista, São Leopoldo, v. 1, n. 3, p. 35-55, jul. 2006.

BRASIL. Parâmetros curriculares nacionais para o ensino médio: linguagens códigos e suas tecnologias. Brasília: MEC/SEB, 2000.

BRASIL. Diretrizes curriculares nacionais gerais para a educação básica. Brasília: MEC/CNE, 2013.

BRASIL. Base nacional comum curricular. Brasília: MEC/CNE, 2017a.

BRASIL. Lei no 9.394, de 20 de dezembro de 1996. Dispõe sobre a Lei de Diretrizes e Bases da Educação Nacional. Brasília: Senado Federal, Coordenação de Edições Técnicas, 2017b.

CAMARGO, B. V.; JUSTO, A. M. Tutorial para o uso do software de análise textual IRAMUTEQ. Brasília: UFSC, 2013.

CERTEAU, M. de. A invenção do cotidiano: 1. artes do fazer. 15. ed. Petrópolis: Vozes, 2002.

DAYRELL, J.; CARRANO, P. Jovens no Brasil: difíceis travessias de fim de século e promessas de um outro mundo. 2002. (mimeo.). 
FRIGOTTO, G. Concepções e mudanças no mundo do trabalho e o ensino médio. In: FRIGOTTO, G.; CIAVATTA, M.; RAMOS, M. (org.). Ensino médio integrado: concepção e contradições. São Paulo: Cortez, 2012. p. 57-82.

GINZBURG, C. Mitos, emblemas e sinais: morfologia e história. São Paulo: Companhia das Letras, 2002.

HAN, B.-C. No enxame: perspectivas do digital. Petrópolis: Vozes, 2018.

HARAWAY, D. J. Manifesto ciborgue: ciência, tecnologia e feminismo-socialista no final do século XX. In: SILVA, T. T. (org.). Antropologia do ciborgue: as vertigens do pós-humano. Belo Horizonte: Autêntica, 2000. p. 33-118.

KOZINETS, R. Netnografia: a arma secreta dos profissionais de marketing. 2010. Available at: http://kozinets.net/wp-content/uploads/2010/11/netnografia_portugues. pdf. Accessed on: Nov. 15, 2018.

KOZINETS, R. Netnografia: realizando pesquisa etnográfica online. Porto Alegre: Penso, 2014.

KRAWCZYK, N. O ensino médio no Brasil. São Paulo: Ação Educativa, 2009.

KUENZER, A. Z. O ensino médio agora é para a vida: entre o pretendido, o dito e o feito. Educação \& Sociedade, Campinas, v. 21, n. 70, p. 15-39, abr. 2000. https://doi. org/10.1590/S0101-73302000000100003

LEVY, P. Cibercultura. São Paulo: 34, 1999.

MONTARDO, S. P.; ROCHA, P. J. Cartografia da utilização da mídia no espaço virtual em Novo Hamburgo: proposta de referencial teórico. Gestão e Desenvolvimento, Novo Hamburgo, v. 2, n. 1, p. 63-73, 2005. https://doi. org/10.25112/rgd.v2i1.1066

MOREIRA, A. F. B. Propostas curriculares alternativas: limites e avanços. Educação \& Sociedade, Campinas, ano 21, n. 73, p. 109-138, dez.2000. https://doi.org/10.1590/ S0101-73302000000400009

POISSANT, L. A passagem do material para a interface. In: DOMINGUES, D. (org.). Arte, ciência e tecnologia: passado, presente e desafios. São Paulo: Editora Unesp, 2009.

REDAÇÃO. O que é hashtag. Canal Tech, 2016. Available at: www.canaltech.com.br/ produtos/o-que-e-hashtag/. Accessed on: Jun. 10, 2019.

RIBEIRO, C. Conheça as redes sociais mais usada no Brasil e no mundo em 2018. TechTudo, 2019. Available at: https://www.techtudo.com.br/noticias/2019/02/ conheca-as-redes-sociais-mais-usadas-no-brasil-e-no-mundo-em-2018.ghtml. Accessed on: Jun. 10, 2019.

SACRISTÁN, G. O currículo: uma reflexão sobre a prática. Porto Alegre: Artmed, 2000.

SALES, S. Tecnologias digitais e juventude ciborgue: alguns desafios para o currículo do ensino médio. In: DAYRELL, J.; CARRANO, P.; MAIA, C. L. (org.).Juventude e ensino médio: sujeitos e currículos em diálogo. Belo Horizonte: UFMG, 2014. p. 229-248. 


\section{ABOUT THE AUTHORS}

Murilo Eduardo NazÁrio has a doctorate in physical education from the Universidade Federal do Espírito Santo (UFES). He is a professor at the Universidade de Vila Velha (UVV).

E-mail:murilo_nazario@hotmail.com

Wagner Dos Santos has a doctorate in education from the Universidade Federal do Espírito Santo (UFES).He is a professor at the same institution. E-mail: wagnercefd@gmail.com

Amarílio Ferreira Neto has a doctorate in educaction from the Universidade Metodista de Piracicaba (Unimep). He is a professor at the Universidade Federal do Espírito Santo (UFES).

E-mail: amariliovix@gmail.com

Conflict of interests: There is no conflict of interest.

Funding: There was no source of funding.

Authors' contributions: Project Management: Ferreira Neto, A. Formal Analysis, Conceptualization, Data Curation, Methodology, Writing - Review e Editing: Nazário, M.E.; Santos, W.; Ferreira Neto, A. Investigation, Writing - First Draft: Nazário, M.E. Supervision, Validation and Visualization: Ferreira Neto, A.; Santos, W.

Received on February 13, 2020

Approved on June 24, 2020 